\title{
PROFETAS E PROFETISMO: IDENTIDADE E MISSÃO
}

Prof. Dr. Pe. Mauro Negro

\section{RESUMO}

O Profeta no Antigo Testamento é uma figura singular. Se há equivalentes dos Profetas bíblicos em outras culturas da antiguidade, o fenômeno é, contudo, único em Israel. É único pela sua própria natureza, pela sua fonte e pela sua argumentação. Os Profetas em Israel apresentam-se como a realização da Palavra do Deus na Aliança e mantém com tudo o ímpeto da paixão que arrebata seu coração e ações. Não uma relação dependente do culto, marcada pelo formalismo ou pela conivência com clichês políticos - pelo contrário, uma relação intensa, de arrebatamento e dedicação que determina sua vida e sua mensagem. O fenômeno que marcou e assinalou as exigências da Aliança é de grande importância como literatura vétero-testamentária.

PALAVRAS CHAVES: Profetas, Profetismo, Aliança. Antigo Testamento. Vocação profética

\section{ABSTRACT}

The Prophet in the Old Testament is a unique figure. If there are equivalents of the biblical prophets in other cultures of antiquity, the phenomenon is, however, unique in Israel. It is unique by its nature, by its source and its argument.

The prophets in Israel presents itself as the fulfillment of the Word of God in Alliance and maintains the momentum with all the passion that enrapture their heart and actions. Not a dependent relationship of the cult, marked by formality or by collusion with political clichés - on the contrary, an intense relationship, the rapture and dedication that determines his life and message. The phenomenon that was noted and the requirements of the Alliance is of great importance as testamentary veterinary literature.

KEY WORDS: Prophets, Prophetism, Alliance. Old Testament. Prophetic vocation 


\section{INTRODUÇÃO}

O Profeta é uma pessoa apaixonada e a paixão é por algo ou alguém. A paixão do Profeta é pelo Senhor que se revelou através de Moisés e se mantém revelando pela sua própria ação na história. O Profeta é um paradigma de ação, de adesão, de arrebatamento pela Palavra do Senhor, que o toma de modo quase absoluto. A história de Jeremias apresenta logo no início do livro homônimo (1,7-10), a seguinte e emblemática passagem:

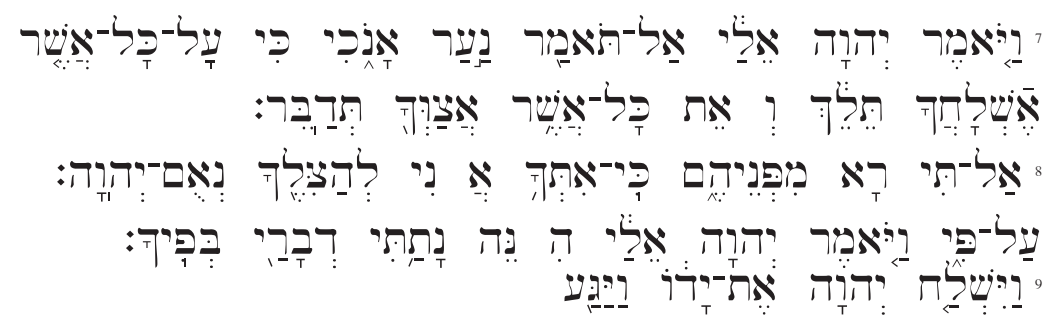

Na tradução:

O Senhor me respondeu: 'Não digas: 'Sou ainda uma criança!' Porque irás a quem eu te enviar e falarás o que eu te ordenar. "Não os temas, porque eu estou contigo para te salvar, oráculo do Senhor".

Então o Senhor estendeu a mão e tocou-me a boca.

E o Senhor me disse: "Eis que ponho as minhas palavras em tua boca.

Vê! Dou-te hoje poder sobre nações e reinos, para arrancar e destruir, para exterminar e demolir, para construir e plantar".

O texto de Jeremias parece muito elucidativo para determinar a figura do Profeta, do homem que deve ser o instrumento de Deus para a ação.

\section{O PROFETA — UM INSTRUMENTO}

\subsection{Ir e falar}

O Profeta deve ir e falar, expor-se para que sua mensagem, a Palavra que deseja e precisa transmitir, seja uma palavra ouvida e acolhida.

154 Revista de Cultura TeológIca - v. 17 - N. 67 - ABR/JUN 2009 
O Profeta é sempre um "agente de campo", alguém que está na linha de frente, dentro de seus limites e realidades. Contudo não em uma trincheira, mas se expondo, propondo, arriscando. Como Ezequiel, Profeta que teve despertada a vocação no exílio:

Ezequiel 1,3: ... a palavra do Senhor foi dirigida a Ezequiel filho do sacerdote Buzi, na terra dos caldeus, junto ao rio Cobar.

No caso de Jeremias há a afirmação de uma escolha e eleição feita anteriormente ao seu nascimento, o que evidencia não um destino cego, mas uma escolha especial, um chamado único e de exclusividade:

Jeremias 1,1: A palavra do Senhor me foi dirigida nestes termos: "Antes mesmo de te formar no ventre materno, eu te conheci; antes que nascesses, eu te consagrei e te constituí profeta para as nações".

Também em Jonas e em outros livros proféticos encontra-se o chamado e a Palavra dirigidos ao Profeta, às vezes em situações dramáticas, outras vezes em meio à agitação política e religiosa:

Jonas 1,1-2: A palavra do Senhor foi dirigida a Jonas filho de Amati:

"Levanta-te, vai a Nínive, a grande cidade,

e anuncia contra ela que a sua maldade chegou até mim".

Miquéias 1,1: Palavra do Senhor dirigida a Miquéias de Morasti, nos dias de Joatão, Acaz e Ezequias, reis de Judá,

o que ele viu a respeito de Samaria e de Jerusalém.

Mesmo os Profetas anteriores apresentam uma escolha da parte do Senhor para ir e falar, como com Samuel, personagem que reúne várias prerrogativas em sua pessoa e exerce uma missão histórica muito ampla:

1 Samuel 3,10: O Senhor veio e, de pé, chamou a Samuel como das outras vezes: "Samuel, Samuel!" Então Samuel respondeu: "Fala, que teu servo escuta!"

O Senhor disse a Samuel: "Eis que vou fazer uma tal coisa a Israel

que toda pessoa que a ouvir ficará com os ouvidos atordoados! Naquele dia vou realizar tudo o que eu disse contra a casa de Eli. 
Vou Ihe anunciar que condeno a sua família para sempre, por causa da iniquidade:

pois sabia que seus filhos amaldiçoavam a Deus e não os impediu.

Por isso jurei à família de Eli:

A iniquidade da família de Eli nunca pode ser expiada por sacrifícios ou oferendas".

Como também com Elias:

1 Reis 17, 1: Elias, tesbita de Tesbi de Galaad, disse a Acab: "Pela vida do Senhor Deus de Israel, a cujo serviço estou, nestes anos não cairá nem orvalho nem chuva, exceto à minha palavra".

Elias no córrego de Carit. Em seguida, a palavra do Senhor Ihe foi dirigida neste teor:

"Parte daqui e toma a direção do oriente;

vai esconder-te junto ao córrego de Carit que se acha a leste do Jordão.

Lá, tu beberás do córrego; dei ordens aos corvos para te levarem provisões".

Elias se pôs a caminho conforme a ordem do Senhor, indo parar junto ao córrego de Carit que corre a leste do Jordão.

O Profeta é sempre um eleito do Senhor, alguém especial para este Senhor que o chama. Não está claro porque este ou aquele indivíduo é chamado para a missão profética, senão que ele é escolhido. Ele exerce uma missão quase nunca "oficial", no sentido de ser em nome dos poderes e instituições estabelecidas. Diversamente a isto parece que ele está quase sempre à margem das instituições, não em função delas, mas sim do Deus de Israel.

\subsection{Não temas: Eu te salvo}

O Profeta não deve temer, não deve sentir-se intimidado perante as forças que, na maior parte das vezes sem tréguas, atacam, mentem, corrompem e até matam a verdade que ele está transmitindo. $O$ Profeta não defende uma mensagem sua, mas uma mensagem, uma verdade, um alerta que vem de seu Deus, do Deus que acompanha Israel desde sua celebrada origem

156 ReVIsta de Cultura TeOlógICA - V. 17 - N. 67 - ABR/JUN 2009 
patriarcal e mosaica. O Profeta é o representante avançado do projeto do Êxodo, especialmente do seu final, quando o povo de Israel, liderado pelo "Profeta" Josué, toma posse da terra prometida e estabelece um novo e único modo de ser e viver. O Profeta não age por si, pela sua fantasia ou por ser um visionário. Ele age por causa do Senhor, ele é "oráculo do Senhor".

Assim, o Profeta não deve temer, não deve deixar-se abater perante as contradições. Jeremias, Profeta sofrido, provado, rejeitado e muitas vezes revoltado consigo e com a mensagem que deve transmitir, também se debate com a profecia que deve apresentar. Ele tem medo em função da posição que esta profecia lhe impõe: ele se isola, se opõe a praticamente todos os contemporâneos, pois não vê solução a não ser o rendimento ao inimigo que ameaça a invasão. Por isso ele é combatido, acusado de conivente com o invasor, traidor da nação e de seus valores. A contradição está mais do que estabelecida e o Profeta sofre interiormente com isto.

De fato, se a mensagem que o Profeta apresenta não é, a princípio, dele ou desejada por ele, mas de seu Deus, ela passa a ser dele pela intensidade com que a apresenta, a defende e por sua causa é perseguido. A palavra do oráculo que envia o Profeta lhe promete também a salvação. Como se dá esta materialmente comunicação, isto somente o Profeta pode saber - pois é algo que foge à literatura profética e toca os símbolos de linguagem e expressão. Ela tem na frente a proposta de salvação. Mas esta salvação também só pôde ser conhecida pelo Profeta, não pelos seus contemporâneos nem pelos leitores hodiernos. Jeremias, que ouve este oráculo e o declara à nação, será no final exilado e certamente assassinado. Não parece um final com muito glamour... Como foi então a salvação por ele anunciada? Somente o próprio Jeremias poderá contar. Mas sua mensagem ou a mensagem do Senhor feita pela boca e pela ação do Profeta estava certa - então sua salvação já começou no julgamento da história que não deixa impunes os que rejeitam a verdade dos fatos e da vida.

\subsection{Tocou a boca}

A boca do Profeta é tocada, pois ele não falará palavras que são suas, mas palavras que são de Deus. Isaías, na visão cósmica em que recebe a vocação e a identidade profética, declara seu temor e provoca com isto a purificação de seus lábios: 
Isaías 6, 4-9: Os gonzos da porta começaram a tremer à voz daquele que clamava e o templo se enchia de fumo. Eu disse então: "Ai de mim! Estou perdido porque sou um homem de lábios impuros, habito no meio de um povo de lábios impuros, e meus olhos viram o rei, o Senhor Todo-poderoso". E um dos serafins voou em minha direção; tinha em sua mão uma brasa que tomara do altar com uma tenaz. Tocou-me a boca e disse: "Eis que isto tocou os teus lábios: foi removida a tua culpa e perdoado o teu pecado". Então ouvi a voz do Senhor que dizia: "Quem enviarei e quem irá por nós?" E eu disse: "Eis-me aqui, envia-me!" E ele disse: "Vai e dize a esse povo: Ouvi, mas sem compreender, olhai sem reconhecer."

\section{4. "As minhas palavras em tua boca"}

As palavras na boca do Profeta o tornam o representante de Deus, do Deus de Israel que realiza ações de salvação. Sua autoridade é clara: ele, o Profeta, é o oráculo do Senhor, deixou de agir e falar por si e o faz agora em nome de seu Deus. As palavras na boca do Profeta não significam apenas palavras ditas, voz humana. São também tantas e tantas ações, realizações, atos simbólicos, às vezes complexos ou até dramáticos, como Oséias que deve tomar como esposa uma prostituta, ou como Jonas que deve anunciar o fim de toda uma imensa cidade como Nínive. Por isso o oráculo dirigido a Jeremias que bem representa e resume a índole do profetismo, continua com três pontos, vertentes de ação e identidade: poder, destruição e construção.

\subsection{Poder sobre nações e reinos}

O poder sobre as nações não é um poder político ou administrativo. Alguns Profetas anteriores, especialmente Josué e Samuel, devem manter as tribos unidas ou a nação com um rumo, um sentido e identidade que se assenta no Deus dos Pais e do Êxodo. Profetas como Natã devem ser a consciência crítica do reino e do rei acusando, aceitando ou rejeitando as ações do monarca. Mas em geral e em especial depois do século VIII, o Profeta não é enviado para legitimar ou partilhar algum poder político. Ele é a crítica deste poder quando este mesmo poder está contra a Torah, a lei dada a Moisés. 
Se a compilação da Torah ainda não é completa até o exílio, está, contudo, já transmitida, em grande parte, oralmente. Está também escrita em textos esparsos e deve ser já observada. As tradições orais da Aliança com os Pais e as tradições orais do Êxodo dão aos Profetas a autoridade, o poder sobre nações e reinos. Se estas nações ou reinos são uma metáfora para os reinos de Judá e Israel ou seus reis singulares ou ainda reinos e nações estrangeiros, isto não é tão importante aqui. $O$ fundamental é a ideia de que o Profeta tem um poder que, no nosso conceito não é realmente "poder", mas sim "autoridade".

\subsection{Arrancar e destruir, exterminar e demolir}

A autoridade é em um primeiro momento, para a destruição. Isto é, no mínimo, conflitante com possíveis ideias positivas da ação de Deus. Mas é isto mesmo: arrancar, destruir, exterminar e demolir - deixar livre o caminho da história para o que é conforme a Aliança com os Pais e no Evento Êxodo. O Profeta não destrói de modo ostensivo, mas através de sua ação simbólica, de sua palavra e presença nos ambientes que frequenta.

\subsection{Construir e plantar}

Às ações de destruição são sobrepostas ações de construção, frutos da autoridade (poder, em algumas traduções) que o Profeta recebe. Isto abre o espaço para a noção de "nova aliança" que Jeremias anuncia:

Jeremias 31, 31-34: Eis que virão dias, oráculo do Senhor em que selarei com a casa de Israel e a casa de Judá uma aliança nova. Não como a aliança que selei com seus pais no dia em que os tomei pela mão para fazê-los sair do Egito, aliança que eles mesmos romperam, embora eu fosse o seu senhor - oráculo do Senhor! Porque esta é a aliança que selarei com a casa de Israel depois desses dias - oráculo do Senhor. Colocarei minha lei no seu seio e a escreverei em seu coração. Então eu serei seu Deus e eles serão meu povo. Eles não terão mais que instruir seu próximo ou irmão, dizendo: "Reconhece o Senhor!" porque todos me conhecerão, dos menores aos 
maiores, oráculo do Senhor, porque perdoarei sua culpa e não mais me lembrarei de seu pecado.

O Profeta e o Profetismo voltam assim à sua índole original que é fazer acontecer o encontro entre Deus, o Senhor, e seu povo, Israel. A aliança é o sinal da comunhão que o Profeta estabelece. Moisés estabeleceu esta Aliança no Êxodo, renovou a Aliança feita com os Pais e agora os Profetas, em seus tempos e situações específicas, fazem acontecer a Aliança com o mesmo Deus, o Senhor que se volta para seu povo e declara: "tu és meu!"

\section{POR QUE A PROFECIA EM ISRAEL?}

Em outros povos existiam profetas e sua ação de profecia. Portanto o fenômeno profético não é exclusivo de Israel. No entanto, deve haver alguma diferença entre a profecia e os profetas presentes nestes povos e os profetas e a profecia em Israel. Tal diferença vem do Agente da profecia ou de seu motivo mais fundamental - Deus mesmo! É Deus que determina o tipo de profecia e consequentemente de Profeta. A profecia é imediatamente ligada à imagem de Deus que é alimentada e vivenciada, ela "serve" aquele Deus que deseja anunciar ou o qual deseja ser anunciado por ela.

Além disso, pode-se perguntar também: por que existe uma profecia, uma situação de profecia ou por que existiram Profetas? E sabendo que a profecia depende do Deus que a inspira ou que ela defende, publica ou anuncia é fácil compreender que o fenômeno profético em Israel é algo único, pois o Deus de Israel é único. Assim, à possível pergunta a respeito do profetismo em geral e do por que em Israel ele é diverso do que existiu em outros povos e culturas pode-se responder: É porque o Deus de Israel é único! É pessoal. É histórico. É encarnado. É personalizado.

\subsection{Deus pessoal}

Porque o Deus de Israel é um Deus que se mostra em encontros pessoais não é anônimo nem um reflexo da natureza1. Enquanto os outros povos veneravam uma quantia enorme de deuses e deusas, a maioria dos

Sigo aqui, de modo quase literal, as anotações de Maximo GRILLI, II pathos della Parola.

I Profeti di Israele. 
quais são forças da natureza personificadas, Israel tem um Deus que está absolutamente destacado das forças naturais. "O Deus de Israel, ao invés, é pessoal, intervém, repreende, anima, chama..." 2. Não é "um" deus entre tantos de um panteão, mas é "o" Deus que tem a identidade da vida, do ser vivo:

Êxodo 3, 14-15: Deus disse a Moisés:

"Eu sou aquele que sou. Assim responderás aos israelitas:

'Eu sou'envia-me a vós". Deus disse ainda a Moisés: "Assim dirás aos israelitas:

O Senhor, o Deus de vossos pais, o Deus de Abraão, Deus de Isaac e Deus de Jacó, envia-me a vós.

Este é o meu nome para sempre, e assim serei lembrado de geração em geração."

O Deus de Israel e Judá é um Deus pessoal que intervém, reprova, motiva, chama, não está alheio ou distante, mas dentro (encarnado) na história de seu povo.

\subsection{Deus histórico}

Porque Deus, o Deus de Israel, o Senhor, se revela na história. Enquanto em outros povos os deuses estão distantes, vendo desde os céus os eventos humanos, o Deus de Israel está dentro da história de seu povo, sofre com esta história, luta nela, vivencia, assume, se distancia, retorna. Os Profetas são os seus representantes, os seus mediadores.

Isaías 6, 6-13: $E$ um dos serafins voou em minha direção; tinha em sua mão uma brasa que tomara do altar com uma tenaz. Tocou-me a boca e disse: "Eis que isto tocou os teus lábios: foi removida a tua culpa e perdoado o teu pecado". Então ouvi a voz do Senhor que dizia: "Quem enviarei e quem irá por nós?"E eu disse: "Eis-me aqui, envia-me!" E ele disse: "Vai e dize a esse povo: Ouvi, mas sem compreender, olhai sem reconhecer. Obceca o coração desse povo endurece seus ouvidos e fecha seus olhos para que não veja com os olhos, não ouça com os

2 Maximo GRILLI, op. cit., pág. 47. 
ouvidos, não compreenda com o coração, e assim não possa converter-se e ser curado!" E eu perguntei: "Até quando Senhor?" Ele respondeu: "Até que as cidades fiquem devastadas, sem habitantes, as casas sem moradores e a terra devastada e desolada". O Senhor afastará os homens para longe e será grande o abandono no meio do país. E se ainda sobrar uma décima parte, esta tornará a ser desbastada como o terebinto e o carvalho que, ao serem abatidos, resta deles apenas um tronco. Seu tronco é uma semente santa.

\subsection{Deus encarnado}

Sendo Deus encarnado na história de Israel Ele exige um empenho ético sem comparação com outras experiências religiosas. Outros profetas em outros povos e religiões não têm a mesma imersão na história que os Profetas de Judá e de Israel, pois os deuses destes povos não se identificam com a nação, são seus deuses, mas não sofrem com a queda e o soerguimento dos que sofrem. $O$ Deus dos Profetas não está alheio à sorte de seu povo, não se mantém distante. Quem se distancia é seu povo. A imagem da esposa e do esposo é talvez a melhor imagem para Israel e Judá e seu Deus, o Senhor. Uma imagem que expõe tensões e desejos, encontros e desencontros, amor e castigo.

\subsection{Deus "personalizado"}

À diferença dos deuses dos povos vizinhos, o Senhor não se deixa controlar por ofertas votivas, por sacrifícios que o "acalmam" ou dirigem. Talvez aqui resida a muito comum resistência dos Profetas a partir do séc. VIII em relação ao culto. Eles acusam tantas vezes o culto exterior como sinal da busca de controlar e agradar a Deus, sendo que tal "agrado" não ocorre neste sentido, mas em ações e sentidos interiores. Joel, cronologicamente posterior a este período histórico, teve tempo de pensar e amadurecer as ideias de rejeição de um culto corrompido e expõe com cores vivas a necessidade da mudança dos próprios sacerdotes, os que estavam próximos do culto.

Joel 2, 12-17: Agora, portanto, oráculo do Senhor, retornai a mim de todo o coração, com jejum, lágrimas e lamentações. 
Rasgai os vossos corações e não as roupas, retornai ao Senhor vosso Deus porque ele é bondoso e misericordioso, lento na cólera e cheio de amor, e se compadece da desgraça. Quem sabe? Talvez volte atrás, se arrependa e deixe após si uma bênção, uma oblação e libação para o Senhor vosso Deus. Tocai a trombeta em Sião! Consagrai um jejum, proclamai uma reunião sagrada! Reuni o povo, convocai a comunidade, congregai os anciãos, reuni os jovens e os lactentes! Que o esposo saia do quarto e a esposa do aposento! Entre o pórtico e o altar chorem os sacerdotes e os ministros do Senhor digam: "Senhor, tem piedade de teu povo! Não entregues ao opróbrio a tua herança para que as nações zombem deles! Por que se diria entre os povos: Onde está o seu Deus?"

\section{CARACTERÍSTICAS DOS PROFETAS DE ISRAEL}

\subsection{Vocação}

O Profeta não o é por profissão, por desejo pessoal, por empenho escolhido e preparado, ma sim por vocação, por um chamado no mínimo misterioso e até sem lógica. Os Profetas ditos escritores não fazem parte de uma "escola de profetas" ou um circulo profético, não são "filhos de profetas", o que se pode encontrar em alguns lugares como em 1 Reis 20, 35 ou 2 Reis 2, 3. Amós, por exemplo, afirma de modo explícito:

Amós 7, 14-15: Amós respondeu e disse a Amasias: "Não sou profeta nem filho de profeta; eu sou vaqueiro e cultivador de sicômoros. Mas o Senhor tirou-me de junto do rebanho e me disse: 'Vai, profetiza a meu povo, Israel!'”

A vocação profética é inesperada, imprevista. O chamado de Samuel é o modelo desta imprevisibilidade desde a origem inesperada (1 Samuel 3, 1-10). Para o jovem Samuel e para o idoso Eli, o que passa a ser necessário é ouvir o Senhor, escutá-lo.

1 Samuel 3, 4-21: Então o Senhor chamou Samuel, e ele respondeu: "Às ordens!" Correu para junto de Eli e disse: "Às tuas ordens! pois me chamaste!" Ele respondeu: "Eu não te 
chamei: volta e deita-te!" Então ele se retirou e foi se deitar. O Senhor chamou outra vez: "Samuel!" Levantou-se Samuel e foi ter com Eli dizendo: "Às tuas ordens! pois me chamaste". Ele respondeu: "Não te chamei, meu filho; vai deitar-te de novo!"É que Samuel ainda não conhecia o Senhor, pois nunca tivera revelação sua. 8Então o Senhor chamou pela terceira vez a Samuel, e ele se levantou e foi para junto de Eli, dizendo: "Às tuas ordens! pois me chamaste". Então Eli se deu conta que era o Senhor que chamava o menino. Por isso disse a Samuel: "Vai deitar-te e se alguém te chamar, responderás: 'Senhor, fala que teu servo escuta!" Samuel se retirou e foi deitar-se no seu lugar. O Senhor veio e, de pé, chamou a Samuel como das outras vezes: "Samuel, Samuel!" Então Samuel respondeu: "Fala que teu servo escuta!" O Senhor disse a Samuel: "Eis que vou fazer uma tal coisa a Israel que toda pessoa que a ouvir, ficará com os ouvidos atordoados! Naquele dia vou realizar tudo o que eu disse contra a casa de Eli. Vou Ihe anunciar que condeno a sua família para sempre, por causa da iniquidade: pois sabia que seus filhos amaldiçoavam a Deus e não os impediu. Por isso jurei à família de Eli: A iniquidade da família de Eli nunca pode ser expiada por sacrifícios ou oferendas". Samuel então foi dormir até a madrugada e abriu as portas do templo do Senhor. Ele tinha receio de comunicar a visão a Eli. Este, porém, o chamou e disse: "Meu filho, Samuel!" e ele respondeu: "Às ordens!" Disse-lhe então: "O que ele te falou? não me encubras nada! Deus te castigue com todo rigor, se me ocultares qualquer coisa do que te falou!" Aí Samuel Ihe referiu todas as palavras, sem nada Ihe ocultar. Eli disse: "Ele é o Senhor; que faça o que Ihe parecer bom!" Samuel crescia e o Senhor estava com ele, não deixando cair por terra nenhuma das suas palavras. Todo Israel, de Dã até Bersabeia, reconheceu que Samuel era um profeta do Senhor, digno de fé. O Senhor continuou a se manifestar em Silo, pois se revelou a Samuel em Silo pela sua palavra.

O Senhor chega a impor-se como em uma coação: 
Amós 3, 7-8: Pois o Senhor Deus não faz coisa alguma sem revelar seu segredo a seus servos, os profetas. Um leão rugiu, quem não temerá? O Senhor Deus falou, quem não profetizará?

\subsection{Palavra e ação}

Em hebraico um substantivo de importância é dābār, palavra ou ação. Palavra e ação estão ligados já na origem desta expressão.

רברָㄱ: dābār é palavra - O Profeta é, primeiramente um homem de palavra, em seguida um homem de ação. O que o Profeta comunica não é fruto apenas de uma visão: ele não é, fundamentalmente um "visionário" como é, e pode ser qualificado um escritor apocalíptico. Se o elemento apocalíptico aparece na sua profecia ${ }^{3}$ é porque ele tem um estilo que tende para o apocalíptico ${ }^{4}$. Quando ocorre uma visão nos Profetas há também um esquema básico ou características básicas para esta visão:

a) A visão é um acontecimento entendido em sentido real;

b) As visões têm acento sobre a palavra ou o sinal simbólico que as acompanha;

c) As visões proféticas não têm o acento na revelação de mistérios inacessíveis, mas têm uma ligação com os fatos da história e exortam as atitudes novas, renovadas ou de conversão.

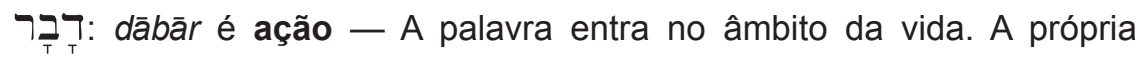
vida do Profeta é palavra: ele faz ou age e isto denota já a palavra que ele deve transmitir. Por exemplo:

- Oséias demonstra isto com seu matrimônio, quando a palavra profética vem através de um ato simbólico de grande eloquência (Oséias 1,2).

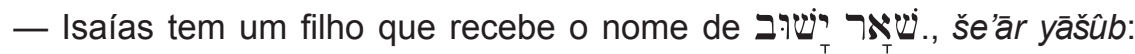
um resto retornará (Isaías 7,3 ), anunciando em uma ação, na identidade de um filho do Profeta, simbolismo de alta eloquência que apesar da destruição

3 Como em Isaías, Ezequiel, etc.

4 Esta é uma chave de leitura dos Profetas: enquanto nos textos apocalípticos existe uma proeminência da visão, nos proféticos a proeminência é da voz, da Palavra que é dirigida ao Profeta. 
e do final que ocorrerá, haverá ainda uma salvação, um resto que retornará de um já pré-anunciado exílio.

- Jeremias por sua vez, não desposa uma mulher nem tem filhos $(16,1-4)$, pois traz consigo uma experiência acentuada de solidão e mesmo de rejeição: sinal de tudo o que se abaterá sobre Judá.

As ações simbólicas estão no âmbito da palavra que os Profetas transmitem.

- Isaías anda nu pelas estradas de Jerusalém (20,2ss) como sinal do que ocorrerá com o Egito em quem confia Israel: estará sem defesa e entregue à própria sorte.

- Jeremias vê um oleiro fabricar um vaso de argila que subitamente é destruído (18,1-13), sinal do que acontecerá com Judá que será aniquilada e Jerusalém totalmente destruída, como aquele vaso.

- Curiosa e contraditoriamente, durante o cerco de Jerusalém, (588-587) Jeremias compra um terreno dentro da cidade (32,2.6-15), sinal de que há uma esperança longínqua no ar.

- Já Ezequiel deve andar como um imigrante errante, sinal do exílio, da deportação (12,3-7).

\subsection{Envolvimento com a história}

O Profeta não está à margem da história, mas mergulhado nela até a medula dos ossos e atuando nela dramaticamente. O profeta demole seguranças humanas, desafia os personagens, acusa, repreende, elogia, tudo de modo intenso, vivo. O Profeta é passional, pois a palavra que ele apresenta não pode ser dita de modo tranquilo, sem exigir um envolvimento afetivo.

Exemplo disto é Natan que, pelo ano 950 se coloca frente a Davi, impedindo-o de construir o Templo, pois não seria um homem como ele que faria uma morada para Deus. No entanto, este Deus fará sua morada em sua descendência, mesmo que em meio às sangrentas disputas dinásticas ocorrerão. Será assegurada a ele uma sucessão (2 Samuel 7). Por outro lado, é o mesmo Natan quem acusa o rei de roubo e assassínio no episódio de Bersabeia (2 Samuel 12). Natan, embora sem um livro homônimo, é como um modelo do profetismo a partir do século VIII. 
Outro exemplo encontra-se em Elias e Eliseu. O primeiro vive no reino de Israel sob o rei Acab que é dominado pela esposa fenícia Jezabel (875-853). Elias se identifica perfeita e totalmente com sua missão profética e cujo nome, אלי:ה,, 'ēliyyāh: só Yhwh (o Senhor) é Deus, designa sua missão e identidade. No final do episódio do embate entre Elias e os profetas de Baal (1 Reis 18), o povo que acompanha a ação declara "...É o Senhor que é

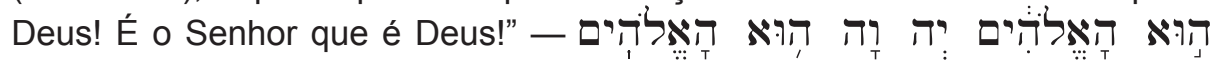
יהוד :, Yhwh hû' hāělōhimm, Yhwh hû' hā'ělōhîm, com uma menção implícita do nome do Profeta. Só o Senhor (Yhwh) é Deus, não os ídolos de Jezabel ou de quaisquer outros soberanos corruptos. Pela sua intrepidez frente às contradições e especialmente pelo seu arrebatamento (2 Reis 1,11), Elias é o sinal da esperança escatológica para o Judaísmo, sendo também o auxílio para o justo que sofre. É neste sentido que nos relatos da paixão em Mateus $(27,46 s s)$ e Marcos $(15,34 s s)$ o clamor de Jesus por Deus é interpretado como sendo o grito do justo sofredor por Elias.

O Profeta é o homem da história, não o homem da ruptura do presente com o futuro. Ele, ao contrário consegue ver, ainda no presente, não apenas a destruição, mas também a semente de algo bom, do que virá como salvação.

\subsection{Intercessão}

O Profeta, além de falar de Deus e em seu Nome ao povo, fala também do povo a Deus, intercede, defende e representa. Amós que é absolutamente impiedoso em relação aos pecados do povo, não deixa de interceder quando sente a necessidade, e exclama:

Amós 7, 1-3: Assim me fez ver o Senhor Deus: Eis que ele formou gafanhotos, quando começava a crescer o feno tardio; era o feno que vem depois da ceifa para o rei. E quando acabaram de devorar toda a erva do país, eu disse: "Senhor Deus, perdoa, eu te peço! Como poderá Jacó subsistir? Ele é tão pequeno!" Então o Senhor compadeceu-se: "Isto não acontecerá" disse o Senhor.

Jeremias por sua vez, perante Deus que pode punir seu povo rebelde, suplica: 
Jeremias 14, 7-9: Se nossas faltas testemunham contra nós, age, ó Senhor, em honra de teu nome! Porque nossas apostasias foram inúmeras, pecamos contra ti. Esperança de Israel, que salvas no tempo da desgraça, por que te comportas como um estrangeiro no país, como um viajante que se desvia para pernoitar? Por que te comportas como um homem perturbado, como um herói que não pode salvar? Mas tu estás em nosso meio, Senhor, e teu nome é invocado sobre nós. Não nos abandones!

O Profeta não busca vantagens para si enquanto todo o restante vai para a destruição. O Profeta expressa, a seu modo, o amor do mensageiro, do oráculo do Senhor. Para ele o outro interessa mais do que a si próprio - e por isso ele intercede!

A intercessão já aparece em Abraão e em Moisés ${ }^{5}$. Com relação ao primeiro é notável a imagem do intercessor perante Deus, nas figuras misteriosas de Gênesis 18. Abraão intercede pelos supostos justos que habitavam as cidades iníquas, mantendo um diálogo intenso e decisivo com o Senhor, na busca de resgatar os poucos que poderiam ser dignos de vida. Ele mudou a decisão da justiça pela ação da misericórdia.

Gênesis 18, 23-33: Abraão aproximou-se e falou: "Vais realmente exterminar o justo com o ímpio? Se houvesse cinquenta justos na cidade, acaso os exterminarias? Não perdoarias o lugar por causa dos cinquenta justos que ali vivem? Longe de ti, proceder assim, fazendo morrer o justo com o ímpio, como se o justo fosse ímpio! Longe de ti! O juiz de toda a terra não faria justiça?" O Senhor respondeu: "Se eu encontrasse em Sodoma cinquenta justos, perdoaria por causa deles a cidade inteira". Abraão prosseguiu e disse: "Sou bem atrevido em falar a meu Senhor, eu que sou pó e cinza. Se dos cinquenta justos faltassem cinco, destruirias por causa dos cinco a cidade inteira?" O Senhor respondeu-Ihe: "Não destruiria se achasse ali quarenta e cinco justos". Insistiu ainda Abraão e disse: "E se

5 Em um sentido mais amplo para a ideia de Profeta podemos dizer que Abraão e Moisés são profetas. Eles o são na medida em que precisam descobrir a vontade de Deus através dos sinais que os cercam. E devem expressá-la, especialmente Moisés, através de palavras e ações. 
houvesse quarenta?" Ele respondeu: "Por causa dos quarenta, não o faria". Abraão tornou a insistir: "Não te irrites, meu Senhor, se ainda falo. E se não houvesse mais do que trinta justos?" Ele respondeu: "Tampouco o faria se encontrasse trinta". Tornou Abraão a insistir: "Já que me atrevi a falar a meu Senhor: e se houver vinte justos?" Ele respondeu: "Não a destruiria por causa dos vinte". E Abraão disse: "Que meu Senhor não se irrite, se falar só mais uma vez: e se não houvesse mais que dez?" $E$ ele respondeu: "Pelos dez, não a destruiria".

E nem os dez justos foram achados em Sodoma! Apenas Ló e sua família.

Moisés é declarado como grande profeta, inigualável em Israel (Deuteronômio 34,10). Em Deuteronômio 18,15 lê-se o anúncio de um Profeta extraordinário, semelhante a Moisés que terá todo o seu ímpeto e grandeza.

Deuteronômio 18, 15-19: O Senhor teu Deus suscitará em teu favor do meio dos irmãos um profeta como eu: é a ele que deverás ouvir. Foi exatamente o que pediste ao Senhor teu Deus, no monte Horeb, no dia da reunião, dizendo: 'Não quero mais ouvir a voz do Senhor meu Deus, nem ver este grande fogo para não acabar morrendo'. Então o Senhor me disse: 'Está bem o que disseram. Vou suscitar-Ihes do meio dos irmãos um profeta semelhante a ti. Porei as minhas palavras em sua boca e ele Ihes comunicará tudo que eu lhe mandar. Eu mesmo pedirei contas a quem não escutar as palavras que ele pronunciar em meu nome.

A imagem de Moisés ou deste grande Profeta, sinal dos tempos messiânicos, está muitas vezes implícita na figura de Jesus, como em João 1,21: E lhe perguntaram: "Mas então quem és? És Elias?" Ele respondeu: "Não sou". "És o Profeta?" E ele respondeu: "Não". Também em João 6, 14: Vendo o sinal que Jesus tinha realizado, aquela gente dizia: "Na verdade, este é o profeta que há de vir ao mundo". E também João 7, 41-42: Ouvindo estas palavras, alguns da multidão começaram a dizer: "Este é realmente o Profeta". Outros diziam: "Ele é o Cristo". Mas outros protestavam: "Por acaso o Cristo virá da Galiléia? Não, diz a Escritura que o Cristo será da família de Davi e virá de Belém , povoado de onde era Davi?" 
Profetas e Profetismo: Identidade e Missão

Moisés, mesmo exercendo a prerrogativa de intercessor, fica ao lado do povo pecador, desejando obter-Ihe o perdão em uma solidariedade admirável:

Números 14, 13-19: Moisés respondeu ao Senhor: "Mas os egípcios sabem que de seu meio tiraste este povo com grande poder, e o dirão aos habitantes desta terra. Eles sabem que tu, Senhor, estás no meio deste povo; que tu, Senhor, te manifestas face a face; que sobre eles vela tua nuvem; que de dia os precedes numa coluna de nuvem e de noite numa coluna de fogo. Se, pois, fizeres morrer este povo como se fosse um só homem, as nações que ouvirem tais notícias a teu respeito, comentarão: 'Foi incapaz de introduzir o povo no país que lhes prometeu, por isso o Senhor os massacrou no deserto'. Portanto, agora é que o meu Senhor deveria manifestar a grandeza de sua força, como tu mesmo disseste: 'o Senhor é paciente e misericordioso; suporta a maldade e a rebeldia, mas não a deixa impune; castiga a maldade dos pais nos filhos até a terceira e quarta geração'. Perdoa pois, a maldade do povo conforme tua grande misericórdia, e da mesma forma como o suportaste desde o Egito até aqui".

\subsection{Rejeição}

O Profeta é um "sinal de contradição", não de incoerência como a expressão contradição poderia ser entendida, mas sim de conflito entre tendências opostas, entre ações conflitantes. O Profeta não tem sucesso em sua missão - ele é, geralmente, um fracassado! Ele não tem ilusões e não espera do povo, do rei ou de quem quer que seja um gesto de apoio. Ele tem amor ao povo que acusa e amor absoluto ao Deus que representa.

Por ser "sinal de contradição" o Profeta é quase sempre rejeitado, o que é uma constante nos livros proféticos. Como em Jeremias 20,2: O sacerdote Fasur filho de Emer, que era o chefe da guarda no templo do Senhor, ouviu Jeremias profetizar estas palavras. Fasur mandou açoitar o profeta Jeremias e prendê-lo no tronco que está na porta superior de Benjamim, no templo do Senhor. Ou como o desconhecido Profeta Urias que tinha seu modelo em Jeremias e é assassinado, o que se lê em Jeremias 26,20-26: Houve ainda, um homem que profetizou em nome do Senhor: Urias filho de Se- 
meías, proveniente de Cariat-larim. Ele profetizou contra esta cidade e este país nos mesmos termos de Jeremias. O rei Joaquim, com seus guerreiros e chefes, ouviu as suas palavras e procurou matá-lo. Quando Urias soube, ficou com medo e fugiu, indo para o Egito. Mas o rei Joaquim enviou Elnatã filho de Acobor, acompanhado de alguns homens, ao Egito. Eles tiraram Urias do Egito e o trouxeram ao rei Joaquim que o mandou matar pela espada e lançar seu cadáver na sepultura comum. Jeremias, contudo, foi protegido por Aicam filho de Safã, de modo que não foi entregue nas mãos do povo para ser morto.

A imagem do Profeta rejeitado é perfeitamente tomada pelo Cristo do Novo Testamento e vivenciada, testemunhando a continuidade da missão e do ímpeto dos grandes homens de Israel que foram o Oráculo do Senhor.

\section{4. "ORÁCULO DO SENHOR"}

\subsection{Em nome do Senhor}

O Profeta fala em nome do Senhor. O mais importante na sua missão é anunciar a Palavra de Adonai, o Deus de Abraão, Isaac e Jacó. Não se trata de ficar de um lado ou de outro dos seus ouvintes, mas sim do lado do Senhor. Este é o sentido principal da vida de um Profeta, seja ele identificado como escritor ou orador.

Às vezes, é feita uma distinção limitada do Profeta e do Profetismo: ele está do lado de um grupo social específico. A realidade dos Profetas é que estão do lado do Senhor. Se o rei está do lado do Senhor, então o Profeta está com o rei; se o rei está indo contra a Torah que expressa a vontade, a Palavra do Senhor, então o Profeta está contra o rei. Se o Israel está cumprindo a Torah ou está contra o Senhor, então o Profeta estará a favor ou contra Israel.

O paradigma ou referência fundamental do Profeta e da Profecia é o Senhor, não uma situação social. Claro que sendo o Senhor a referência fundamental do Profeta, ele vai ficar realmente do lado de quem está sendo privado do Senhor pela possível opressão de um governante ou de um poder adverso. Mas fundamentalmente o Profeta é o Oráculo do Senhor, agindo 
em Nome do Senhor, isto é, na sua pessoa e autoridade, visto que o Nome é a própria presença da pessoa ou realidade denominada.

\subsection{Palavra criadora}

Palavra é, em hebraico, רדרָ, dabar. Esta palavra é potente, é criadora. Cada palavra que Deus diz produz algo, transforma e forma. O poema da Criação em Gênesis é marcante nesta ideia:

Gênesis 1, 3.6.7: Deus disse: "Faça-se a luz"! E a luz se fez. Deus disse: "Faça-se um firmamento entre as águas, ()() E assim se fez.

Esta Palavra é dita e algo acontece porque ela foi dita, é a Palavra Criadora que os Profetas dizem. É o oráculo que Huaiss define assim: Substantivo masculino: Na Antiguidade, resposta de uma divindade a quem a consultava; Derivações por metonímia: a divindade consultada ou sacerdote encarregado da consulta à divindade e transmissão de suas respostas; o local, o santuário onde se realiza essa consulta. Como expressão de teologia: a verdadeira revelação divina; a palavra de Deus e de seus profetas. Como derivação por sentido ou metáfora: verdade irrefragável, infalível; dito, decisão, opinião etc. infalível, irrefutável, ou que revela grande autoridade. Também: indivíduo cujas palavras, conselhos, opiniões etc. inspiram total confiança; são sábios, têm grande autoridade.

A palavra oráculo tem em si a ideia de algo que vem da divindade e por isso tem autoridade. É a palavra decisiva dos Profetas que revela, faz conhecer, leva à conversão, acusa, liberta e antes disto tudo, cria. É Tרד Tרד dabar.

\subsection{Palavra que chama, elege, envia, denuncia, anuncia}

A mesma Palavra faz uma eleição ou escolha e, depois de escolher pela eleição, às vezes sem um motivo aparente, envia. Assim acontece com Abrão/Abraão que ouve o chamado e segue o que ouviu.

Gênesis 12,1-6: O Senhor disse a Abrão: "Sai de tua terra, de tua parentela, da casa de teu pai e vai para a terra que te mostrarei. Farei de ti um grande povo e te abençoarei, engrande-

172 Revista de Cultura TeológIca - v. 17 - N. 67 - ABR/JUN 2009 
cendo teu nome, de modo que se torne uma bênção. Abençoarei os que te abençoarem, e amaldiçoarei os que te amaldiçoarem. Com teu nome serão abençoadas todas as famílias da terra". Abrão partiu como o Senhor Ihe havia dito e Ló foi com ele. Ao sair de Harã, Abrão tinha 75 anos. Levando consigo a mulher Sarai, o sobrinho Ló e todos os bens que possuíam, bem como os escravos que haviam adquirido em Harã, Abrão partiu rumo à terra de Canaã, aonde chegaram. Abrão atravessou o país até o santuário de Siquém, até o carvalho de Moré. Naquele tempo estavam os cananeus no país.

A Palavra do Senhor é dirigida a Abrão/Abraão em diversas ocasiões. É frequente uma espécie de audição-visual no sentido de que o Senhor dirige a ele sua Palavra e o que acontece é uma aparição completa: visão e audição - uma teofania.

A teofania da circuncisão:

Gênesis 17,1: Quando Abrão tinha 99 anos, apareceu-lhe o Senhor e Ihe disse: "Eu sou o Deus Poderoso. Anda na minha presença e sê perfeito.

A teofania de Mambré/Mamrê:

Gênesis 18,1-2: Outra vez o Senhor apareceu a Abraão junto ao carvalho de Mambré. Estava sentado à entrada da tenda, no maior calor do dia. Levantando os olhos, viu parados perto dele três homens. Assim que os viu, saiu correndo a seu encontro e se prostrou por terra.

Depois da provação de Abraão, o Senhor Ihe dirige a Palavra e afirma ser ela um oráculo:

Gênesis 22,16-17: e Ihe falou: "Juro por mim mesmo - oráculo do Senhor - uma vez que agiste deste modo e não recusaste teu único filho, eu te abençoarei e tornarei tão numerosa tua descendência como as estrelas do céu e como as areias da praia do mar.

Assim também com Moisés. Ele ouve a Palavra do Senhor que o envia para a missão de libertação e legislação: 
Êxodo 3,4-6: O Senhor viu que Moisés se aproximava para observar e Deus o chamou do meio da sarça: "Moisés! Moisés!" Ele respondeu: "Aqui estou!" Deus Ihe disse: "Não te aproximes daqui! Tira as sandálias dos pés, pois o lugar onde estás é chão sagrado". E acrescentou: "Eu sou o Deus de teu pai, o Deus de Abraão, o Deus de Isaac, o Deus de Jacó". Moisés cobriu o rosto, pois temia olhar para Deus.

A Palavra é o centro da ação profética. Por isso o Profeta é o Oráculo do Senhor. Oráculo no sentido de $7 \underset{T}{T}$ Ț, dabar, Palavra criadora, de eleição, de arrebatamento. Ela é a força dos Profetas que os leva a anunciar e denunciar - anunciar a vontade do Senhor e a distância que vai se formando entre o Povo de Israel e este seu Senhor, a ponto deste Povo desprezar a Palavra:

Jeremias 6,9-10: Assim diz o Senhor Todo-poderoso: Rebuscarão como a uma vinha, o resto de Israel! Que tua mão, como a do vindimador, repasse sobre os sacramentos! A quem falarei e testemunharei para que eles ouçam? Eis que seus ouvidos são incircuncisos, e não podem escutar. Eis que a palavra do Senhor tornou-se para eles um objeto de escárnio, eles não gostam dela!

Miquéias 6,1- 3: Ouvi, pois, o que diz o Senhor: "Levanta-te, abre um processo diante das montanhas, e que as colinas ouçam tua voz!" Ouvi, montanhas, o processo do Senhor, prestai ouvidos, fundamentos da terra, porque o Senhor abriu processo contra o seu povo, e com Israel ele disputa. "Meu povo, que te fiz eu? Em que te cansei? Responde-me!

\subsection{Palavra Criadora-Carne-Oráculo}

A Palavra que cria quando é dita (Gênesis $1,1-2,4 a$ ) é retomada no Novo Testamento. Esta Palavra-Oráculo é mais do que som ou articulação vocal, visual. A Palavra-Oráculo é presença física, na declaração da Carta de João:

1 João 1,1-3: O que era desde o princípio, o que ouvimos, o que vimos com os olhos, o que contemplamos e nossas mãos

174 ReVISTA de CULtURA TeOlógIcA - V. 17 - N. 67 - ABR/JUN 2009 
apalparam no tocante ao Verbo da vida - porque a vida se manifestou e nós vimos e testemunhamos, anunciando-vos a vida eterna que estava com o Pai e nos foi manifestada - o que vimos e ouvimos, nós também vos anunciamos a fim de que também vós vivais em comunhão conosco. Ora, nossa comunhão é com o Pai e seu Filho, Jesus Cristo. Nós vos escrevemos estas coisas para nossa alegria ser completa!

A Palavra-Oráculo é transformadora da realidade na medida em que vai se tornando ela mesma, realidade, Carne, na afirmação do prólogo de João:

João 1,1.3.14.16-18:

No princípio era a Palavra e a Palavra estava com Deus, e a Palavra era Deus.

Todas as coisas foram feitas por meio dela e sem ela nada se fez do que foi feito.

E a Palavra se fez carne e habitou entre nós;

vimos a sua glória, a glória de Filho único do Pai, cheio de graça e verdade.

Pois da sua plenitude, todos nós recebemos graça sobre graça.

Porque a Lei foi dada por meio de Moisés,

a graça e a verdade vieram por Jesus Cristo.

Ninguém jamais viu a Deus.

O Filho único de Deus, que está junto ao Pai,

foi quem no-lo deu a conhecer.

A Palavra Criadora-Oráculo que se faz Carne, se faz gente, pessoa humana em Maria. É a Palavra de Deus que gera seu Filho em Maria. Ela se torna História, Ação, Presença física, não apenas força verbal ou força histórica, mas realmente presente, palpável.

Mateus 1, 20-23: Mas enquanto assim pensava, eis que um anjo do Senhor Ihe apareceu em sonho e disse: "José filho de Davi não tenhas medo de receber Maria, tua esposa, pois o que nela foi gerado vem do Espírito Santo. Ela dará à luz um filho, e tu lhe porás o nome de Jesus. É ele que salvará o povo de seus pecados". Tudo isso aconteceu para que se cumprisse o que o Senhor falou pelo profeta: Eis que a Virgem conceberá e dará à luz um filho, e o chamarão com o nome de Emanuel que significa: Deus conosco. 
A Palavra Criadora-Oráculo passa a ser Palavra Criadora-EncarnadaOráculo e realiza a salvação: a retomada do caminho.

Lucas 1,38: Disse então Maria: "Eis aqui a serva do Senhor. Faça-se em mim segundo tua palavra!" E dela se afastou o anjo.

Maria assume o papel de fazer acontecer a Palavra. Ela agora é quem deixa que se faça, quem abre o caminho para a ação. É a comunhão sublime entre o Deus revelado do Primeiro Testamento, Palavra Criadora, e que agora se torna humano dentro de um ser humano. Este ser humano deve também aceitar, livremente, a ação de Deus. Por isso Maria pode dizer: faça-se. E a Palavra se faz humana, entra na história e faz história.

A Escritura tem como chave de compreensão esta ideia: o Oráculo. Oráculo enquanto Palavra Criadora, Palavra que se encarna, Palavra que se revela. Segundo a Dei Verbum:

Dei Verbum n 2: Aprouve a Deus. na sua bondade e sabedoria, revelar-se a Si mesmo e dar a conhecer o mistério da sua vontade (cf. Efésios 1,9), segundo o qual os homens, por meio de Cristo, Verbo encarnado, têm acesso ao Pai no Espírito Santo e se tornam participantes da natureza divina (cf. Efésios 2,18; 2 Pd 1,4). Em virtude desta revelação, Deus invisível (cf. Colossenses 1,15; 1 Timóteo 1,17), na riqueza do seu amor fala aos homens como amigos (cf. Éxodo 33, 11; João 15,1415) e convive com eles (cf. Baruc 3,38), para os convidar e admitir à comunhão com Ele. Esta "economia» da revelação realizase por meio de ações e palavras intimamente relacionadas entre si, de tal maneira que as obras, realizadas por Deus na história da salvação, manifestam e confirmam a doutrina e as realidades significadas pelas palavras; e as palavras, por sua vez, declaram as obras e esclarecem o mistério nelas contido. Porém, a verdade profunda tanto a respeito de Deus como a respeito da salvação dos homens, manifesta-se-nos por esta revelação, em Cristo, que é, simultaneamente o mediador e a plenitude de toda a revelação (Cf. Mateus 11,27; João 1,14 e 17; 14,6; 17, 1-3; 2 Coríntios 3,16 e 4,6; Efésios 1, 3-14).

Isto tudo posto entendemos que a experiência profética em Israel foi um Evento de largo alcance, de intensidade e impacto que apenas a Histó-

176 ReVISTA de CULTURA TEOLÓGICA - V. 17 - N. 67 - ABR/JUN 2009 
ria pode avaliar. Cada Profeta, a seu modo, foi uma aproximação da Torah, das tradições orais e escritas que iam formando a Escritura. A paixão que eles expressam não é uma ideia meramente subjetiva mas uma constatação constante nos textos proféticos. Eles são apaixonados pela mensagem que transmitem, pela origem ou a Fonte original desta mensagem. A leitura dos Profetas e dos livros proféticos deve ocupar um espaço e uma atenção sempre mais marcante na espiritualidade e na pastoral.

Prof. Dr. Pe. Mauro Negro, OSJ

Professor de Teologia Bíblica na Faculdade de Teologia

Nossa Senhora da Assunção, PUC-SP.

mauronegro@uol.com.br

\section{BIBLIOGRAFIA}

BALLARINI, Teodorico. BRESSAN, Gini. Profetismo e profetas em geral. In: BALLARINI, T. BRESAN, G. VIRGULIN, S. VALLAURI, E. COLELLA, P. MATTIOLI, A. Profetismo e profetas em geral. Isaías, Jeremias, Lamentações, Baruc, Carta de Jeremias, Ezequiel. v. II/3. Petrópolis : Vozes, 1977.

GRILLI, Massimo. I/ pathos della Parola. I profeti di Israele. Milano: Paoline, 2000. MARCONTICI, Benito. Profeta e parola profetica. In: MARCONCITI, Benito et alii. Profeti e apocalittici. Torino : Elle Di Ci, 1995.

RENDTORFF, Rolf. Teologia dell'Antico Testamento. Volume I: I testi canonici. Torino : Claudiana, 1999.

RENDTORFF, Rolf. Introduzione all'Antico Testamento. Storia, vita sociale e letteratura d'Israele in epoca biblica. $3^{a}$ ed. Torino : Claudiana, 2001.

SHÖKEL, L.A.; SICRE DIAZ, J.L. Profetas I. $2^{a}$ ed., São Paulo : Paulus, 2004.

SICRE, José Luís. Profetismo em Israel. O Profeta. Os Profetas. A Mensagem. $3^{a}$ ed. Petrópolis : São Paulo: Vozes, 2008.

VV.AA. Il messaggio della Salvezza. Il profetismo e i profeti. Torino: Elle Di Ci, 1977. 